\title{
Perilaku Berkendara Sepeda Motor pada Siswa SMP Ditinjau dari Izin dan Persepsi Orang Tua
}

\author{
Naomi Srie Kusumastutie*1, Destria Rahmita ${ }^{2}$, Frans Tohom ${ }^{3}$ \\ ${ }^{123}$ Politeknik Keselamatan Transportasi Jalan \\ E-mail: *naomis@pktj.ac.id
}

Received 01-02-2021; Reviewed 09-04-2021; Accepted 13-04-2021

Journal Homepage: http://ktj.pktj.ac.id/index.php/ktj

DOI: $10.46447 / \mathrm{ktj} . v 8 i 1.298$

\begin{abstract}
Abstrak
Semakin maraknya fenomena anak di bawah umur yang telah bisa berkendara sepeda motor dewasa ini semakin memprihatinkan. Salah satu faktor yang ditengarai menjadi penyebabnya adalah izin orang tua terhadap anak untuk berkendara. Untuk itu studi ini bertujuan untuk mendapatkan gambaran perilaku berkendara anak di bawah umur ditinjau dari izin dan persepsi orang tua. Responden studi ini adalah orang tua siswa SMP di 13 sekolah di Kota Tegal. Pemilihan sekolah dilakukan secara purposive sampling, dengan jumlah responden 711 orang. Instrumen pengumpulan data dalam studi ini adalah kuesioner yang disajikan secara online. Analisis data dilakukan secara deskriptif kuantitatif. Hasil studi ini menunjukkan bahwa terdapat $37 \%$ responden yang melaporkan bahwa anaknya sudah bisa mengendarai sepeda motor. Mayoritas responden yang anaknya sudah bisa berkendara sepeda motor mengizinkan anaknya tersebut berkendara (64,3\%). Terdapat $5,6 \%$ responden yang anaknya belum bisa berkendara sepeda motor berpeluang untuk mengizinkan anaknya tersebut berkendara. Mayoritas responden mempersepsikan bahwa anak di bawah umur sudah bisa berkendara sepeda motor merupakan perilaku yang berbahaya, tidak menguntungkan, dan melanggar peraturan lalu lintas. Diperlukan studi lebih lanjut untuk mengungkap faktor-faktor berperan penting dalam mendorong orang tua untuk mengjinkan anaknya berkendara.
\end{abstract}

Kata kunci: berkendara, di bawah umur, izin, orang tua, persepsi

\section{PENDAHULUAN}

Sepeda motor merupakan moda transportasi yang paling populer. Populasi sepeda motor di Indonesia mengalami peningkatan yang sangat signifikan dari tahun ke tahun. Menurut data BPS, pada tahun 2019 jumlah sepeda motor di Indonesia sebanyak 126.588.509 kendaraan (Badan Pusat Statistik, 2020). Jumlah ini mengalami peningkatan sebanyak $5,12 \%$ dari jumlah tahun sebelumnya. Minat masyarakat menggunakan sepeda motor ini tidak lepas dari kemudahan kepemilikan kendaraan ini. Harga yang relatif murah dan biaya operasional lebih rendah dibanding mobil membuat kendaraan ini menjadi primadona di jalanan di Indonesia.

Namun demikian, tingkat keselamatan moda ini sangatlah rendah. Bahkan disebutkan bahwa sepeda motor merupakan moda transportasi yang paling berbahaya (Shinar, 2017). Menurut WHO risiko fatalitas jika terjadi tabrakan pada sepeda motor hampir 20 kali lipat dibandingkan dengan mobil. Di Indonesia sendiri kecelakan yang 
melibatkan sepeda motor menduduki proporsi tertinggi, yaitu mencapai 74\% (World Health Organization, 2018).

Dalam mengendarai sepeda motor diperlukan kemampuan yang handal, baik secara teknik maupun psikis. Mengendarai sepeda motor lebih menuntut perceptual skill maupun vehicle control dibandingkan dengan mengemudikan mobil (Shinar, 2017). Tidak seperti pengemudi yang dilindungi rumah-rumahan, perlindungan bagi pengendara sepeda motor terbatas pada helm dan perlengkapan yang dipakainya, seperti jaket maupun sepatu. Dengan demikian jika terjadi tabrakan maka perlindungan yang dimiliki tidak sebaik pengemudi. Disamping itu, pengendara sepeda motor cenderung berkendara secara agresif, yaitu dengan kecepatan tinggi maupun berkendara secara zig zag. Hal inilah yang mempengaruhi tingkat keselamatan pada pengendara sepeda motor.

Salah satu cara untuk mengurangi tingkat risiko pada pengendara sepeda motor adalah dengan mengatur batasan usia pengendara sepeda motor. Di dalam UU Nomor 22 Tahun 2009 Tentang Lalu Lintas dan Angkutan Jalan (Pemerintah Republik Indonesia, 2009) dinyatakan bahwa batas minimal usia kepemilikan SIM C adalah 17 tahun. Pembatasan umur ini terkait dengan kematangan perkembangan psikologis individu, yaitu kemampuan kontrol diri maupun pembuatan keputusan, disamping juga terkait dengan kebutuhan akan pendidikan lalu lintas (Fatonah \& Nurdibyanandaru, 2018). Hal ini akan terkait dengan kemampuan berkendara yang berkeselamatan.

Namun dewasa ini fenomena pengendara sepeda motor di bawah umur semakin jamak ditemui di lingkungan kita. Siswa SMA bahkan SMP sudah semakin banyak kita jumpai mengendarai sepeda motor. Beberapa studi bahkan menunjukkan bahwa anak telah belajar mengendarai sepeda motor sejak duduk di bangku SD (Fatonah \& Nurdibyanandaru, 2018; Kusumastutie, 2018).

Keprihatinan ini tergambar pada studi yang dilakukan di tiga sekolah di Kota Tegal (Kusumastutie, 2018). Pada studi tersebut ditemukan bahwa 80,3\% responden yang terdiri dari siswa SMP dan SMA yang berusia di bawah 17 tahun telah dapat mengendarai sepeda motor. Jika dilihat dari tingkat pendidikannya, responden siswa SMP yang telah dapat mengendarai sepeda motor sebanyak 65\%, sedangkan responden siswa SMA sebanyak 95\%. Selain itu dilaporkan juga bahwa di lingkungan tempat tinggal $50,8 \%$ responden terdapat lebih dari 10 orang anak di bawah umur yang telah dapat mengendarai sepeda motor.

Studi tersebut juga mengungkapkan bahwa ada kecenderungan bahwa usia untuk belajar mengendarai sepeda motor untuk pertama kalinya semakin muda (Kusumastutie, 2018). Responden berusia 16 tahun pertama kali belajar mengendarai sepeda motor pada usia 13 tahun, sedangkan responden dengan usia lebih muda pertama kali belajar mengendarai sepeda motor pada usia 11 tahun. Hal ini sejalan dengan studi Fatonah \& Nurdibyanandaru ( 2018) yang juga menunjukkan bahwa responden studi mereka telah belajar mengendarai sepeda motor sejak duduk di bangku SD.

Secara garis besar terdapat dua faktor penyebab anak di bawah umur berkendara sepeda motor, yaitu faktor internal dan eksternal (Nurlia, Komariah, \& Waluya, 2017). Faktor penyebab secara internal adalah adanya izin orang tua, jarak tempuh dari rumah ke sekolah yang jauh, maupun efisiensi waktu. Faktor eksternal merupakan faktor lingkungan, yaitu lingkungan yang membebaskan, pengaruh teman, 
maupun gaya hidup. Dari berbagai faktor tersebut faktor izin orang tua ditengarai sebagai faktor utama penyebab anak di bawah umur berkendara sepeda motor.

Faktor orang tua ini juga terungkap juga pada studi lain yang meninjau maraknya pengendara sepeda motor di bawah umur ini melalui Theory of Planned Behavior (Kusumastutie, 2016). Berdasarkan kuesioner terbuka yang diberikan kepada responden berumur di bawah 17 tahun terkait perilaku berkendara sepeda motor pada usia di bawah 17 tahun, responden menjawab pertanyaan yang mengungkap behavioral belief (apakah keuntungan ....), normative belief (siapa yang setuju atau tidak setuju ....), dan control belief (faktor apa yang mempermudah atau mempersulit ....) dengan jawaban-jawaban yang menjurus pada peran orang tua. Sebagai contoh jawaban yang diberikan responden adalah sebagai berikut: 1) keuntungan berkendara sepeda motor pada usia di bawah 17 tahun adalah tidak merepotkan orang tua, 2) orang tua menyetujui berkendara sepeda motor pada usia di bawah 17 tahun, dan 3) izin orang tua akan mempermudah untuk berkendara sepeda motor pada usia di bawah 17 tahun.

Studi kualitatif terhadap tiga orang tua yang memiliki anak di bawah umur yang telah berkendara sepeda motor (Fatonah \& Nurdibyanandaru, 2018) menunjukkan bahwa kemudahan mobilitas untuk ke sekolah menjadi pertimbangan utama mereka mengizinkan anak mereka mengendarai sepeda motor. Menanggapi anaknya telah dapat mengendarai sepeda motor, orang tua merasa senang dan menganggapnya wajar. Dari hasil studi ini disimpulkan bahwa orang tua memegang perangan yang sangat signifikan terhadap peluang anak di bawah umur untuk mengendarai sepeda motor.

Studi mengenai faktor penyebab maraknya pengendara sepeda motor di bawah umur masih sangatlah terbatas. Untuk itu studi ini ingin menguak lebih dalam faktor penyebabnya dari aspek orang tua. Hal ini dikarenakan orang tua menjadi pihak yang sangat signifikan dalam pengasuhan anak, dalam hal ini untuk menentukan batas waktu anak diizinkan untuk mengendarai sepeda motor. Dalam studi ini perilaku berkendara anak di bawah umur akan dieksplorasi dari izin dan persepsi orang tua. Hasil studi ini nantinya akan bermanfaat dalam menentukan intervensi kepada para orang tua guna menekan peluang anak di bawah umur mengendarai sepeda motor.

\section{METODE \\ Responden Studi}

Studi ini dilakukan di Kota Tegal, dengan orang tua siswa SMP sebagai responden. Jumlah SMP di Kota Tegal adalah 34, yang terdiri dari 18 sekolah negeri dan 16 sekolah swasta (http://sekolah.data.kemdikbud.go.id/). Jumlah keseluruhan siswa SMP di Kota Tegal adalah 12.826 orang, yang terdiri dari 10.666 orang siswa sekolah negeri dan 2.160 orang siswa swasta.

Pada awalnya survei akan dilakukan pada delapan sekolah yang mewakili masing-masing satu sekolah negeri dan swasta untuk setiap kecamatan, dengan pemilihan sekolah dilakukan secara acak. Jumlah responden pada perencanaan awal ini adalah sejumlah 720 orang. Namun demikian, dikarenakan terdapat kendala dalam izin studi serta kecukupun jumlah responden pada sekolah dimaksud maka pemilihan sekolah tidak memungkinkan dilakukan secara acak. 
Pemilihan sekolah dilakukan secara purposive sampling, yaitu SMP yang berada di wilayah Kota Tegal dan mewakili proporsi jumlah siswa secara keseluruhan (sekolah dengan jumlah siswa relatif banyak). Surat izin studi disampaikan 22 sekolah, namun demikian ada sembilan sekolah yang tidak dapat berpartisipasi dalam studi ini. Hal ini disebabkan adanya kendala dalam penyampaian kuesioner dari pihak sekolah kepada orang tua siswa terkait dengan kondisi pandemi. Dengan demikian survei dilakukan pada $13 \mathrm{SMP}$, yang terdiri dari 10 sekolah negeri dan tiga sekolah swasta. Jumlah responden dalam studi ini adalah 711 orang. Sebaran responden berdasarkan kecamatan dan sekolah dapat dilihat pada Tabel 1.

Tabel 1. Sebaran responden

\begin{tabular}{lcccccc}
\hline \multirow{2}{*}{ Kecamatan } & \multicolumn{3}{c}{ Jumlah Sekolah } & \multicolumn{3}{c}{ Jumlah Siswa } \\
\cline { 2 - 7 } & Negeri & Swasta & Jumlah & Negeri & Swasta & Jumlah \\
\hline Tegal Selatan & 2 & 0 & 2 & 61 & 0 & 61 \\
Tegal Timur & 3 & 2 & 5 & 157 & 96 & 253 \\
Tegal Barat & 3 & 1 & 4 & 293 & 9 & 302 \\
Margadana & 2 & 0 & 2 & 95 & 0 & 95 \\
\hline \multicolumn{1}{c}{ Jumlah } & 10 & 3 & 13 & 606 & 105 & 711 \\
\hline
\end{tabular}

\section{Instrumen Pengumpulan Data}

Instrumen pengumpulan data pada studi ini adalah kuesioner. Penyampaian kuesioner dilakukan secara online. Link kuesioner online disampaikan kepada guru, kemudian guru menyampaikan link tersebut kepada orang tua siswa melalui WAG orang tua siswa. Sebagai apresiasi kepada responden diberikan suvenir berupa pulsa/saldo gopay/saldo OVO yang diundi untuk 100 responden.

Kuesioner dengan data kategori yang disajikan secara online, dinilai tepat untuk mengatasi kendala pengumpulan data yang disebabkan oleh kondisi pandemi COVID19 yang sedang terjadi. Dengan pilihan respon berupa data kategori maka kuesioner yang disusun akan lebih sederhana dibanding jika menggunakan jenis data yang lain. Dalam menentukan pilihan responnyapun responden dapat melakukan lebih mudah karena pilihan hanya berupa pilihan jawaban singkat dengan dua pilihan respon.

\section{Teknik Analisa Data}

Data akan dianalisis secara deskriptif kuantitiatif. Analisis utama meliputi izin responden terhadap anak untuk berkendara serta persepsi responden mengenai bahaya, keuntungan, dan pelanggaran dari anak di bawah umur yang berkendara sepeda motor.

\section{HASIL DAN PEMBAHASAN Profil Responden}

Link kuesioner diberikan kepada 13 sekolah yang bersedia untuk berpartisipasi dalam studi ini. Guru kemudian menyebarkan link tersebut pada WAG orang tua siswa di setiap kelas. Sebelum orang tua yang mendapatkan link mengisi kuesioner, terlebih dahulu diberikan informed concent, yang berisi penjelasan sekaligus meminta persetujuan untuk menjadi responden dalam studi ini. Dari jawaban yang terekam 
terdapat 132 orang yang tidak bersedia berpartisipasi dan 711 orang yang bersedia berpartisipasi. Dengan demikian tingkat pengembalian kuesioner cukup besar, yaitu $84 \%$. Selanjutnya analisis dilakukan untuk 711 responden ini. Profil responden dalam studi ini sebagaimana yang ditunjukkan pada Gambar 1.
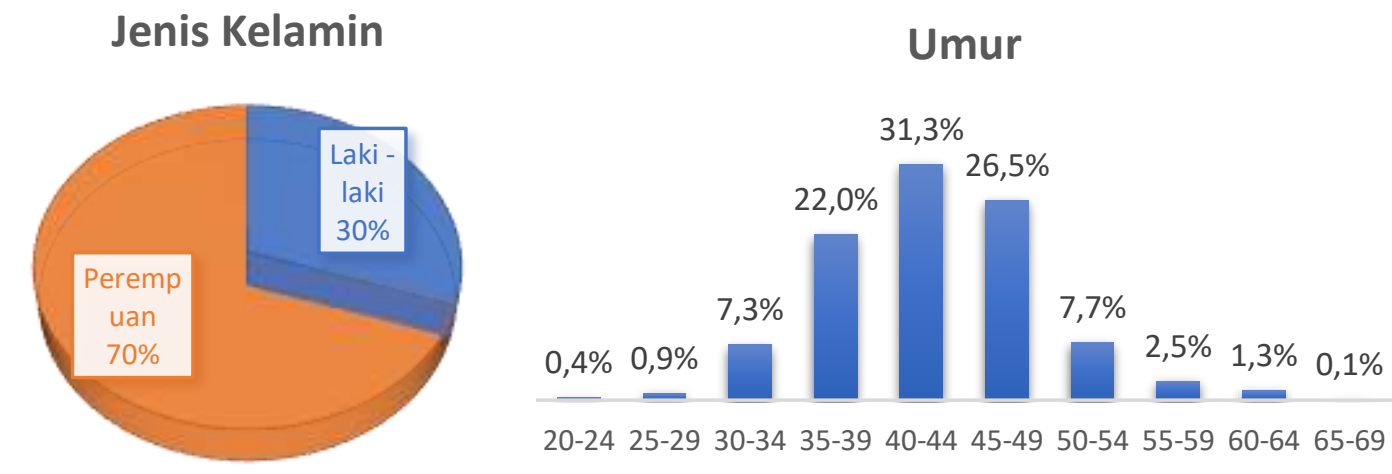

Gambar 1. Profil responden berdasar jenis kelamin dan umur

Berdasarkan Gambar 1 diketahui bahwa mayoritas responden adalah perempuan (70\%) dan berumur 40-44 tahun. Selanjutnya Gambar 2 menunjukkan profil responden berdasarkan pendidikan dan pekerjaan.

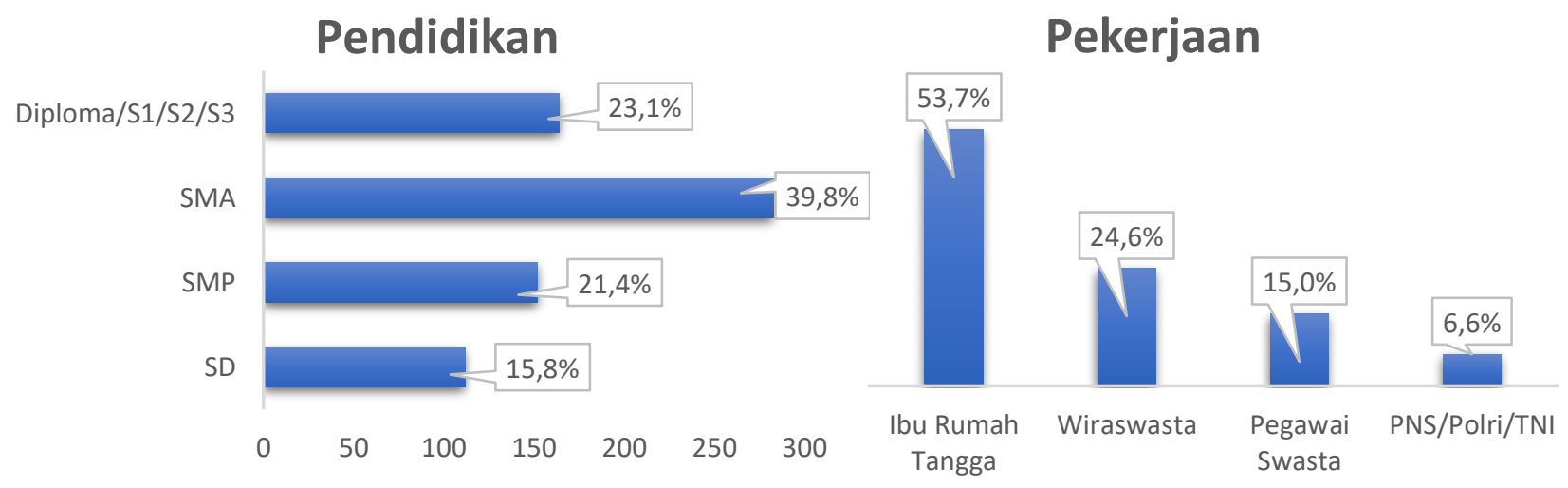

Gambar 2. Profil responden berdasar pendidikan dan pekerjaan

Berdasarkan Gambar 2 diketahui bahwa mayoritas responden berpendidikan SMA $(39,8 \%)$ dan berstatus sebagai ibu rumah tangga $(53,7 \%)$. Hal ini dipengaruhi faktor bahwa link kuesioner online dibagikan di WAG orang tua siswa yang mayoritas diikuti oleh ibu siswa yang bersangkutan. Selanjutnya status ekonomi responden dapat dilihat dari jumlah pengeluaran bulanan dan jumlah sepeda motor yang dimiliki sebagaimana yang disajikan pada Gambar 3. 
Jumlah Pengeluaran

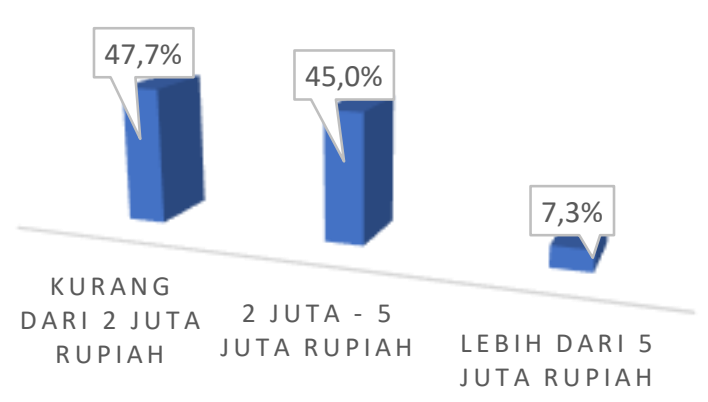

Jumlah Sepeda Motor yang

Dimiliki

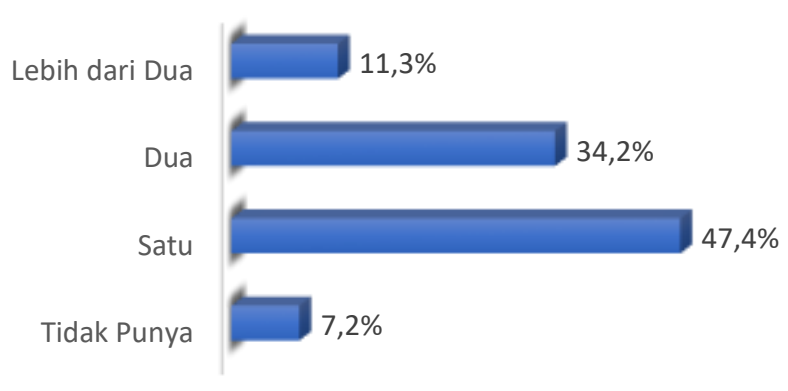

Gambar 3. Gambaran status ekonomi responden

Berdasarkan Gambar 3 dapat diketahui bahwa status ekonomi mayoritas responden berada pada status ekonomi menengah ke bawah. Hal ini ditengarai dari jumlah pengeluaran mayoritas responden, di bawah Rp2.000.000,00 (47,7\%) dan antara Rp2.000.000,00 sampai dengan Rp5.000.000,00 (45\%). Seperti diketahui bahwa UMR Kota Tegal tahun 2020 adalah sebesar Rp1.800.000,00. Jika dilihat dari kepemilikan sepeda motor, mayoritas responden memiliki satu buah sepeda motor (47\%).

\section{Profil Anak}

Anak responden yang terlibat dalam studi ini mayoritas berjenis kelamin lakilaki (54\%) dan berada pada kelas 7 (45\%). Dari keseluruhan anak responden tersebut terdapat $37 \%$ yang sudah dapat mengendarai sepeda motor. Lebih lanjut profil anak repsonden dalam studi ini dapat disajikan pada Gambar 4.
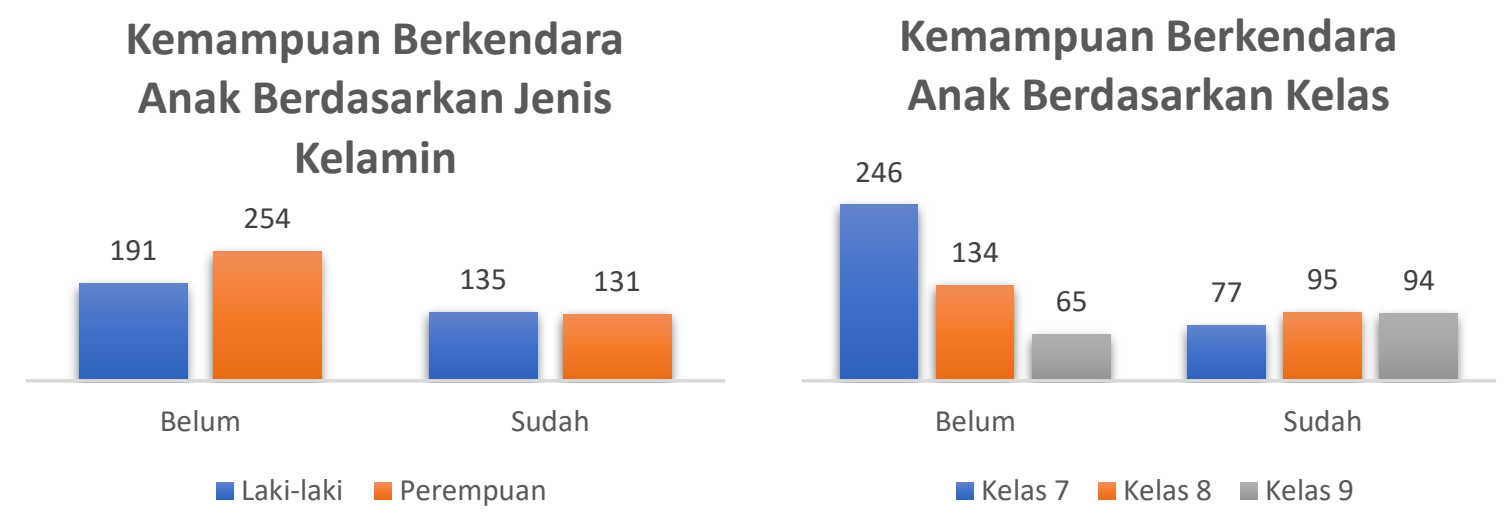

Gambar 4. Kemampuan berkendara anak berdasarkan jenis kelamin dan kelas

Berdasarkan Gambar 4 dapat dilihat bahwa anak berjenis kelamin laki-laki lebih banyak yang sudah bisa mengendarai sepeda motor dibanding dengan anak berjenis kelamin perempuan. Anak yang duduk di kelas 8 juga lebih banyak yang sudah bisa mengendarai sepeda motor dibandingkan dengan dua kelas yang lain. 


\section{Izin orang tua terhadap anak untuk berkendara sepeda motor}

Secara umum antara responden dan pasangannya memiliki keputusan yang sama dalam mengizinkan anak untuk berkendara. Hal ini sebagaimana yang terlihat pada Gambar 5. Pada responden yang anaknya sudah bisa berkendara, proporsi perbedaan pemberian izin antara responden dan pasangannya hanya selisih $0,4 \%$ saja. Satu hal yang perlu diperhatikan disini adalah bahwa terdapat 35\% orang tua yang sebenarnya tidak mengizinkan anaknya untuk berkendara walaupun anaknya telah bisa berkendara. Pada responden yang anaknya belum bisa berkendara selisih proporsi perbedaan pemberian izin antara responden dan pasangannya lebih besar, yaitu $1,6 \%$.

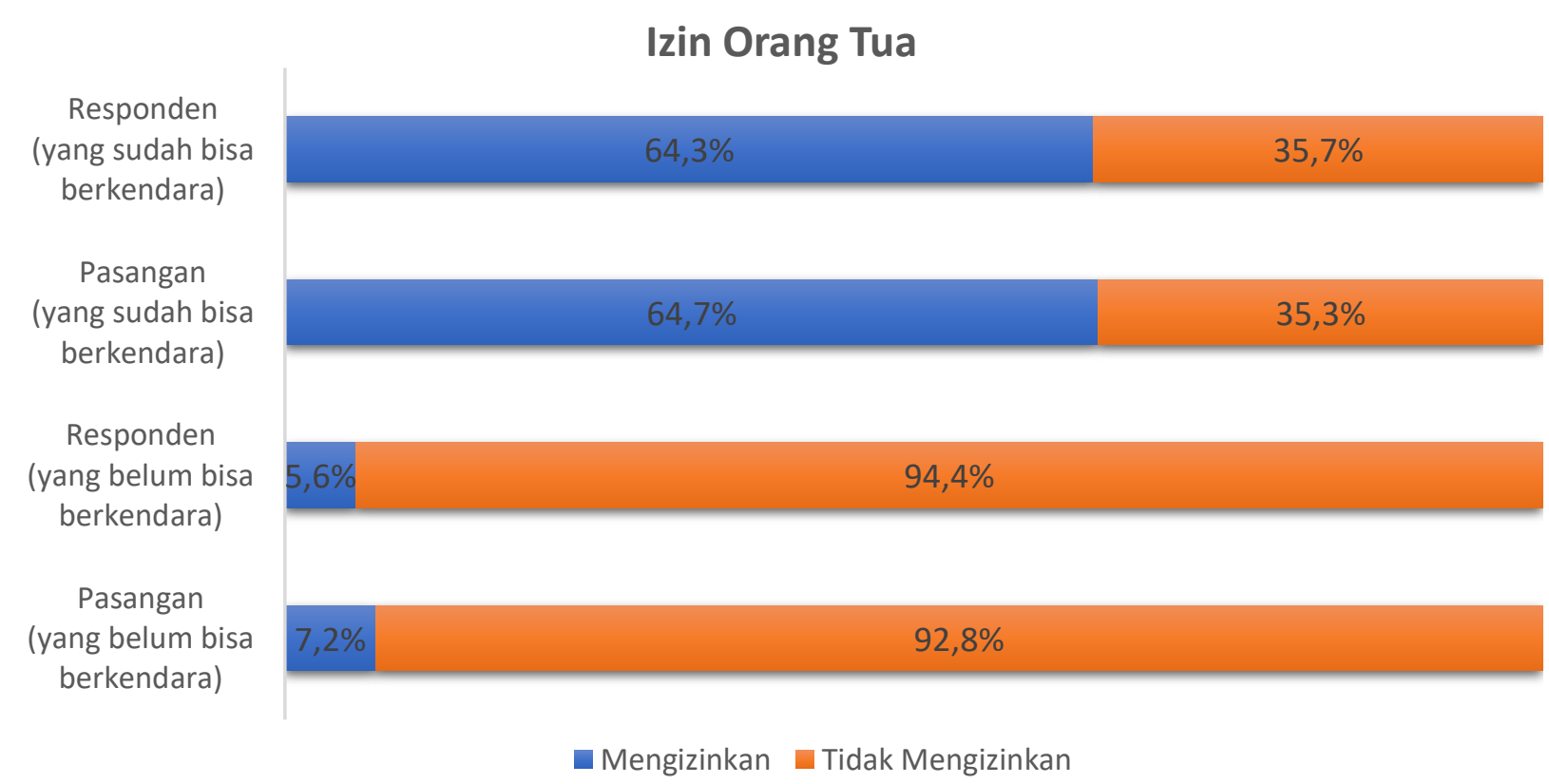

Gambar 5. Izin Orang Tua terhadap anak untuk berkendara sepeda motor

\section{Persepsi orang tua terhadap anak yang sudah bisa berkendara sepeda motor}

Selanjutnya Gambar 656 menyajikan persepsi responden terhadap anak di bawah umur yang sudah bisa berkendara sepeda motor. Persepsi ini meliputi persepsi bahaya, persepsi keuntungan, dan persepsi pelanggaran. Mayoritas responden, baik yang anaknya sudah bisa berkendara ataupun belum, menyatakan bahwa berkendara sepeda motor di bawah umur adalah berbahaya. Proporsi responden yang mempersepsi berbahaya lebih tinggi pada responden yang anaknya belum bisa berkendara (97,8\%). Mayoritas responden juga mempersepsi bahwa berkendara sepeda motor di bawah umur adalah tidak menguntungkan. Namun demikian proporsi persepsi menguntungkan dan tidak hampir sama pada responden yang anaknya sudah bisa berkendara $(46,2 \%$ dan 53,8\%). Terakhir, mayoritas responden juga mempersepsi bahwa berkendara sepeda motor di bawah umur adalah melanggar 
peraturan lalu lintas. Dengan selisih prosentase sebesar $25,6 \%$ untuk responden yang anaknya belum bisa berkendara.

\section{Persepsi orang tua}

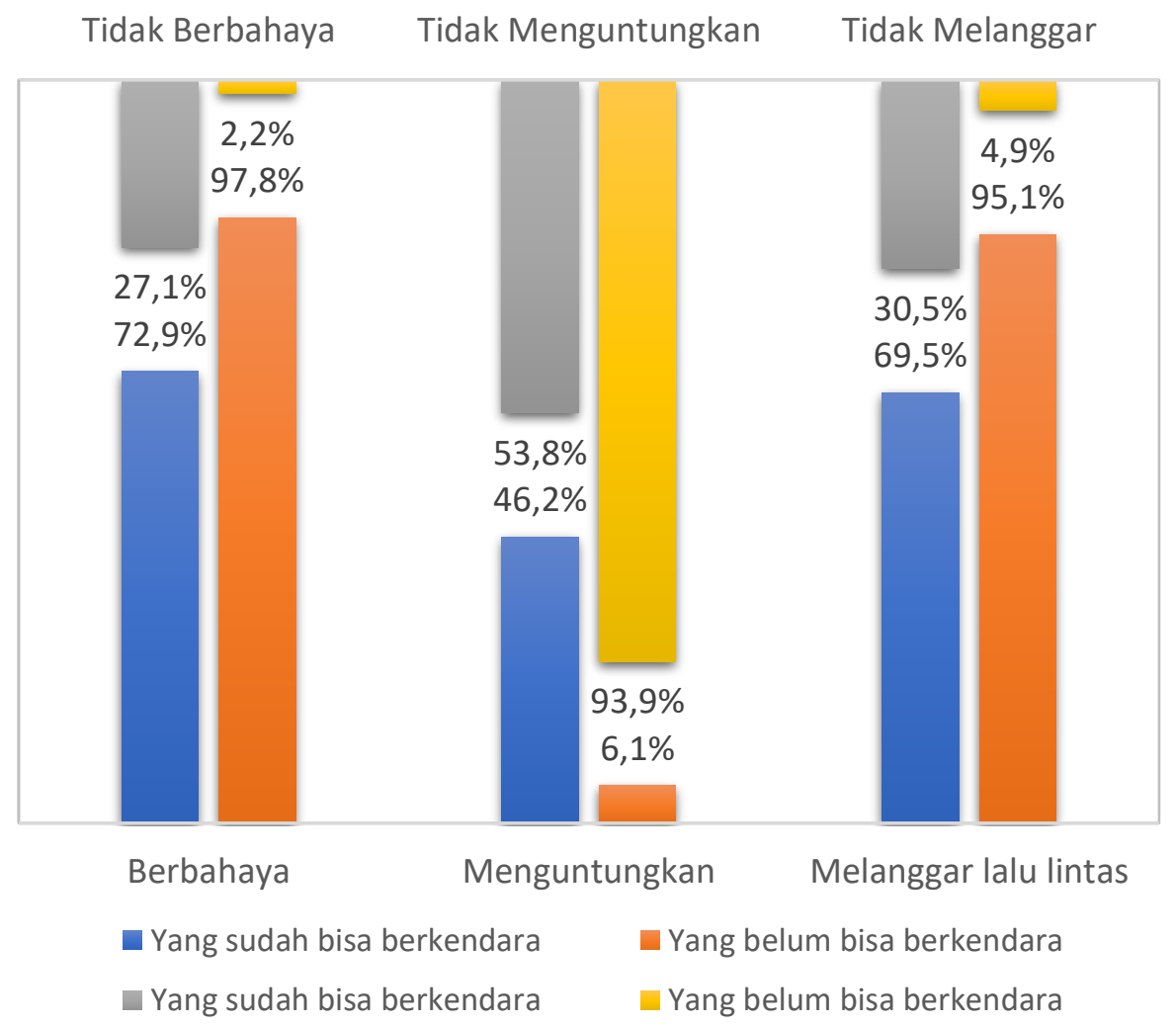

Gambar 65. Persepsi responden terhadap anak di bawah umur yang sudah bisa berkendara sepeda motor

\section{Pembahasan}

Berawal dari keprihatinan akan semakin maraknya anak di bawah umur yang mengendarai sepeda motor, studi ini bertujuan untuk memaparkan perilaku berkendara pada anak di bawah umur ditinjau dari izin dan persepsi orang tua. Hal ini didasari keyakinan bahwa orang tua menjadi orang yang menjadi aktor utama dalam pengasuhan anak.

Responden dalam studi ini mayoritas adalah perempuan (70\%) berusia sekitar 40 tahun (72\%), berpendidikan SMA (40\%) dan berstatus ibu rumah tangga (54\%). Hal ini dimungkinkan karena kuesioner disampaikan pada WAG orang tua yang mayoritas anggotanya adalah ibu dari siswa yang bersangkutan. Hal ini dimungkinkan karena pada masyarakat kita masih berlaku stereotip bahwa ibu memiliki tanggung jawab lebih besar pada pengasuhan anak. Kecenderungan perempuan untuk lebih berpartisipasi pada pengisian kuesioner dibandingkan laki-laki juga muncul pada studi lain. 
Responden pada studi ini cenderung berasal dari keluarga menengah ke bawah. Hal ini bisa dilihat dari pengeluaran bulanan keluarga. Mayoritas responden memiliki pengeluaran bulanan keluarga di bawah Rp5.000.000,00, hanya $7 \%$ dari responden yang memiliki pengeluaran di atas Ro5.000.000,00. Sepeda motor merupakan alat transportasi yang dimiliki oleh mayoritas responden, hanya $7 \%$ responden yang melaporkan tidak memiliki sepeda motor di rumahnya. Hal ini menandakan bahwa memang benar sepeda motor merupakan moda yang paling populer pada masyarakat kita.

Keprihatinan mengenai maraknya anak di bawah umur yang sudah berkendara sepeda motor tergambar begitu nyata pada hasil studi ini. Terdapat $37 \%$ responden yang melaporkan bahwa anaknya sudah bisa mengendarai sepeda motor. Melalui studi ini dapat diketahui bahwa orang tua memang memegang peranan penting terkait dengan fenomena anak di bawah umur yang sudah dapat berkendara sepeda motor ini. Peran penting orang tua ini dapat dilihat dari tingginya izin orang tua terhadap anak untuk berkendara sepeda motor pada responden yang anaknya sudah bisa berkendara sepeda motor, yaitu sebesar $64,3 \%$ untuk responden dan $64,7 \%$ untuk pasangan responden. Temuan mengenai pentingnya peran orang tua ini mengkonfirmasi temuan pada beberapa studi sebelumnya (Fatonah \& Nurdibyanandaru, 2018; Kusumastutie, 2016; Nurlia et al., 2017). Pada responden yang anaknya belum bisa berkendara sepeda motor, terdapat 5,6\% responden dan $7,2 \%$ pasangan responden yang mungkin akan mengizinkan anaknya berkendara sebelum memiliki SIM. Tentu saja hal ini merupakan suatu hal yang perlu diantisipasi.

Gambaran mengenai persepsi orang tua terhadap bahaya, keuntungan, dan pelanggaran lalu lintas terkait anak yang sudah bisa berkendara sepeda motor yang didapatkan oleh studi ini merupakan temuan yang menarik. Baik pada responden yang anaknya sudah bisa berkendara sepeda motor maupun belum, ditemukan bahwa responden cenderung mempersepsikan berkendara di bawah umur sebagai perilaku yang berbahaya, tidak menguntungkan, dan melanggar peraturan lalu lintas. Persepsi berbahaya diungkapkan oleh $72,9 \%$ responden yang anaknya sudah bisa berkendara dan $97 \%$ responden yang anaknya belum bisa berkendara. Persepsi tidak menguntungkan diungkapkan oleh $53,8 \%$ responden yang anaknya sudah bisa berkendara dan $93,9 \%$ responden yang anaknya belum bisa berkendara. Persepsi melanggar peraturan lalu lintas diungkapkan oleh $69,5 \%$ responden yang anaknya sudah bisa berkendara dan 95,1\% responden yang anaknya belum bisa berkendara. Meskipun demikian, kecenderungan ini tampak lebih mencolok pada kelompok responden yang anaknya belum bisa berkendara sepeda motor. Pada responden yang anaknya sudah bisa berkendara proporsi persepsi menguntungkan dan tidak menguntungkan hampir seimbang.

Beberapa studi terdahulu melaporkan bahwa persepsi merupakan salah satu faktor yang dapat memengaruhi perilaku individu. Sebagai contoh, persepsi risiko berpengaruh terhadap perilaku keselamatan berkendara (Darmawan \& Puspitasari, 
2019) ataupun penggunaan sabuk keselamatan (Salihat \& Kurniawidjaja, 2010). Dalam studi ini persepsi negatif (berbahaya, merugikan, dan melanggar peraturan) ditemukan sebagai persepsi mayoritas pada kedua kelompok responden. Hal ini dapat berimplikasi bahwa penilaian seseorang terhadap konsekuensi perilaku tidak menjadi pertimbangan untuk berperilaku atau tidak, dalam hal ini mengijinkan aanak berkendara atau tidak. Namun demikian masih diperlukan studi lebih lanjut untuk memastikan peranan persepsi orang tua terhadap keputusan untuk mengijinkan anak berkendara.

\section{SIMPULAN}

Studi ini telah berhasil mendapatkan gambaran mengenai perilaku berkendara pada anak di bawah umur, khususnya siswa SMP, ditinjau dari izin maupun persepsi orang tua. Berdasarkan hasil studi dapat diketahui bahwa $37 \%$ responden yang melaporkan bahwa anaknya sudah bisa mengendarai sepeda motor. Sebanyak $64,3 \%$ responden yang anaknya sudah bisa berkendara sepeda motor mengizinkan anaknya tersebut berkendara. Sebanyak 5,6\% responden yang anaknya belum bisa berkendara sepeda motor berpeluang untuk mengizinkan anaknya tersebut berkendara. Mayoritas responden mempersepsikan bahwa anak di bawah umur sudah bisa berkendara sepeda motor merupakan perilaku yang berbahaya, tidak menguntungkan, dan melanggar peraturan lalu lintas. Diperlukan studi lebih lanjut untuk mengungkap faktor-faktor berperan penting dalam mendorong orang tua untuk mengizinkan anaknya berkendara.

\section{DAFTAR PUSTAKA}

Badan Pusat Statistik. (2020). Statistik Indonesia 2020. In Statistical Yearbook of Indonesia. Jakarta.

Darmawan, F. A., \& Puspitasari, N. B. (2019). Analisis Pengaruh Persepsi Resiko dan Persepsi pada Driving Task terhadap Perilaku Keselamatan Berkendara. Industrial Engineering Online Journal, 8(3), 1-7.

Fatonah, S. R., \& Nurdibyanandaru, D. (2018). Peran Oran Tua yang Memiliki Anak Sebagai Pengendara Sepeda Motor. Jurnal Psikologi Pendidikan dan Perkembangan, 7, 67-79. Diambil dari http://journal.unair.ac.id/filerPDF/110810241_ringkasan.pdf

Kusumastutie, N. S. (2016). Perilaku Berkendara Sepeda Motor pada Remaja Usia di Bawah 17 Tahun Ditinjau Dari Theory of Planned Behavior. Kota Tegal.

Kusumastutie, N. S. (2018). Perilaku Berkendara Sepeda Motor pada Remaja Berusia di Bawah 17 tahun. Jurnal Keselamatan Transportasi Jalan, 5(1), 1-18.

Nurlia, D. A., Komariah, S., \& Waluya, B. (2017). Faktor-Faktor Penyebab Maraknya Pengendara Motor di Bawah Umur di Desa Rancamanyar Kecamatan Baleendah Kabupaten Bandung. Sosietas, 72 , 381-385. Diambil dari ejournal.upi.edu/index.php/sosietas/article/view/10354

Pemerintah Republik Indonesia. (2009). Undang-Undang Republik Indonesia Nomor 22 Tahun 2009 Tentang lalu Lintas dan Angkutan Jalan. Jakarta: Pemerintah Republik Indonesia.

Salihat, I. K., \& Kurniawidjaja, L. M. (2010). Persepsi Risiko Berkendara dan Perilaku 
Penggunaan Sabuk Keselamatan di Kampus Universitas Indonesia, Depok. Kesmas: National Public Health Journal, 4(6), 275. https://doi.org/10.21109/kesmas.v4i6.167

Shinar, D. (2017). Traffic Safety And Human Behavior. Bingley: Emerald Publishing. World Health Organization. (2018). Global Status Report On Road Safety 2018. Geneva. 